FOCUS: Journal of International Business Volume 4, Issue 1, January-June 2017, pp. 83-94 doi: 10.17492/focus.v4i01.9537

\title{
Foreign Institutional Investment and Economic Growth: A Case Study of Indian Economy
}

\author{
Neeta Tripathi*
}

\begin{abstract}
A major feature of economic reforms in India since 1991 has been a progressive liberalisation of external capital flows, especially non debt creating ones like Foreign Direct investment (FDI) and Foreign Institutional Investment (FII).This opened a new door for the foreign investors (FIIs) to invest in India due to which a large number of foreign institutional investors flocked towards India. In this paper, we make an effort to study cause and effect relationship between FIIs' inflows and economic growth in India. The study covers the period from 1994 to 2016. The pragmatic relationship between FII inflows and economic growth has been examined by applying Engle- Granger Cointegration test, Granger Causality test and further VAR model. The results of the study have given no backing to the speculation that FII inflows have the capability of impacting the process of economic growth in India. Further, we have also found that economic growth is not a substantial determinant of FII inflows in India.
\end{abstract}

Keywords: Foreign institutional investment; Gross Domestic Product; Economic growth; Vector Auto Regressive model; Granger causality test.

\subsection{Introduction}

Offshore Investments are those investments which are made by occupants of a nation in the form of financial assets, furthermore, helps in process of production of another nation. After the opening up of the boundaries for capital development these investments have become fundamentally important. It can influence balance of payments situation of the beneficiary nation. In developing nations there was an incredible need of outside capital. India, being a capital scare nation, has taken number of measures to attract foreign capital since the beginning of reforms in 1991.

*Assistant Professor, Dyal Singh College (M), University of Delhi, Delhi, India.

(Email id: neeta_2612@yahoo.co.in) 
As India is presently following the process of capital account liberalisation, it might have huge sway on the foreign capital and especially on the FII, as this would influence short term stability in the capital markets. In the recent years, several scholars have investigated issues identified with FPI (Foreign Portfolio investment), both from financial and international business aspects. Further, a few studies have attempted to investigate the conceivable determinants of FII inflows in India.

The global capital flows such as direct and portfolio flows might have immense positive impact on the economic growth of the nations. The nations with developed capital markets can take advantage from these worldwide capital flows. As the size of these capital flows is large, it is vital to understand the conduct and impact of these flows on the domestic capital markets and economy, particularly at time when India is liberalising its capital account policy. In this background the present paper makes an attempt to look at the cause and effect relationship between FII flows and the economic growth from the period 1994 to 2016. In Section 2, we briefly provide objective and rationale of the study. In Section 3, we review various studies in order to provide the basic framework. In Section 4, we introduce our data and their sources. In Section 5 research methodology adopted in the paper is discussed. Empirical analysis and research findings are explained in section 6. The summary and conclusions are presented in the last section.

\subsection{Objective and Rationale}

The role and significance of FIIs in the last few years has increased manifold as a result of globalisation of financial markets. The Indian economy is emerging as one of the leading destination for foreign institutional investment because of its attractive GDP growth rate, robust corporate performance and investment friendly environment. As a result FII flows have become such important players in the Indian stock market whose sneeze in the markets can give the wider economy a cold. In this background the present paper aims to fill the gap (by using advance financial econometrics such as Unit Root test, Engle-Granger Co-integration test, Granger Causality test and VAR) that certainly exists as far as the knowledge about the cause and effect relationship between FII flows and economic growth is concerned.

\subsection{Review of Literature}

Numerous studies have been done to identify the FIIs inflows and some of them have been reviewed in this section. Merton (1987) uncovered that the expected return in 
the capital market with unlimited investor base is more than the restricted base. $\mathrm{He}$ argued that diversified capital market is favourite destination for foreign investors. Investor base of the stock market broadens with the entry of foreign investors which in turn, improves risk sharing capability and increased diversification and reduced risk premium for country specific volatility. Ma and Kao (1990) found that appreciation in currency negatively influence the domestic stock market. Worldwide capital flows is presently seen as a noteworthy hotspot for expanding the industrial development of developing nations. Further, it brings a heap of advantages such as capita innovation, expertise and now and again as the market access (Chitre, 1996).

Agarwal (1997) utilising pooled information from five nations from 1986 to 1993 and for India utilizing month to month information from Jan. 1993 to Dec. 1994, uncovered that inflation rate of the domestic nation antagonistically influences the FPI. Prasuna (1999) investigated the determinants of FII investments in India utilising data from January 1993 to March 1998. It was uncovered from the study that lagged FII investment, percentage change in BSE Sensex and BSE Sensex swing out to be critical determinants of FII investments, whereas, exchange rate, interest and forex had been observed to be irrelevant.

Lensiket al., (1999) analysed the effect of unverifiable capital streams on the development of sixty developing nations amid the 1990's. They differentiate between aggregate capital flows, official capital flows and private capital flows. They concluded that volatile capital flows negatively affect financial market and growth in developing nations. Kumar (2001) examined the impacts of FII inflows on the Indian stock market represented by the Sensex utilising month to month information from January 1993 to December 1997. It was also concluded from the study that the FII flows did not react to fleeting changes or specialised position of the market and they were more driven by fundamentals. Moreover, it has been demonstrated that a few times-capital flows might really swarm out or substitute domestic investment from the result of financial market with business sector power. In this manner, it gets to be critical to analyse the effect of capital flows on domestic investment so that the effect of capital flows on economic growth can be evaluated (Misra, et, al. 2001).

Chakrabarti (2001) utilised monthly information to look at the nature and cause for FIIs net inflow to the Indian equity market amid the 1993-99 periods. He found that FIIs net inflow is associated with the returns on the equity market and that FIIs inflows are more probable to be the impact than the cause on the returns. Capital flows might add to economic growth rate of the host economy by expanding the capital. Further, the high growth rates as additionally, result in better investment climate by improving more capital flows in the host country. In this way, the capital - growth relationship is a 
subject of causality with a plausibility of two-way relationship (Duttaray and Mukhopadhya, 2003).

Gordon and Gupta (2003) discovered causation running from FII inflows to return in BSE. They located that given the enormous quantity of investments, overseas investors should count on a function of marketplace makers and book their earnings, i.e., they could purchase financial assets when the prices are declining in this way raising the asset prices and sell when the asset prices were increasing. Trivedi and Nair (2006) in their paper endeavoured to explore the determinants of FIIs inflows to India. The consequences of the study uncovered that returns and volatility in the Indian stock market emerge as the primary determinants of FIIs inflows. Tripathy (2007) attempted to examine the dynamic relationship between stock market, market capitalization and net FII investment in India amid the period from June 2002 to June 2005 by utilizing Granger Causality Test and Vector Auto Regression Model. He found that stock return and market capitalization affected net FII flows in the normal heading over a short time period.

Gangadhar and Reddy (2008) analysed investments patterns and trends of FIIs and their impact on securities exchange liquidity and unpredictability. The study inferred that FIIs have emerged as the market movers in India. Mishra et al. (2010) have made an endeavour in their paper to test the causality between FIIs investment and the real economic growth in India over a period 1993:Q1 to 2009:Q2. They found that bidirectional causality running between these two variables. Further, they proposed that the Indian policy makers can help the country to move towards high growth trajectory by formulating attractive investment policies. It has been seen from the review of literature that there is few work is done to dissect the casual relationship between FII net inflows and economic growth. Further, as an after-effect of liberalisation process numerous progressions have occurred in the Indian Stock Market. Consequently, it is felt that there is a need to examine whether FIIs are the cause or effect of economic growth in India.

\subsection{Data}

The main aim of the present study is to examine the casual relationship between net FII flows and economic growth in India. The present study is based on quarterly information of Net FII inflows and GDP (Gross Domestic Production) of India. The study covers the period from January 1994 to December 2015. Economic growth in India is measured as a log difference of GDP. The information of Gross Domestic Product has been taken at factor cost and at constant prices. The source of the abovementioned data 
is SEBI (Securities and Exchange Board of India) Handbook of Statistics and RBI (Reserve Bank of India) database. We define economic growth as follows:

Economic growth $=\log \mathrm{GDP}_{\mathrm{t}}-\operatorname{LogGDP}_{\mathrm{t}-1}$ where,

$\operatorname{LogGDP}_{\mathrm{t}}=\log$ difference of GDP at time period $\mathrm{t}$

$\operatorname{LogGDP}_{\mathrm{t}-1}=\log$ difference of GDP at time period $\mathrm{t}-1$

\subsection{Research Methodology}

The following methodology has been adopted to test the casual relationship between FII flows and Indian economic growth.

\subsection{Unit root test}

If $\mathrm{y}_{\mathrm{t}}$ is a random walk, then $\Delta \mathrm{y}_{\mathrm{t}}$ must be stationary. A data series must be stationary if its mean and variance are constant (non-changing) over time and the value of covariance between two time periods depends as it were on the distance or lag between the two time periods and not on the real time at which the covariance is processed. The correlation between a series and its lagged values are accepted to depend just on the length of the lagand not when the series began. A series having these properties is known as a stationary time series. It is zero or as 1(0). The unit root test checks whether a data series is stationary or not. Stationary condition has been tried utilizing Augmented Dickey-Fuller (ADF) The ADF approach controls for higher-order correlation by including lagged difference terms of the dependent variable to the righthand side of the regression equation.

To perform the $\mathrm{ADF}$ test we estimated the following regression equation:

$$
\# Y_{\mathrm{t}}=\alpha_{0}+\beta_{0 \mathrm{t}}+\lambda \mathrm{y}_{\mathrm{t}-1}+\Sigma \mathrm{y}_{\mathrm{i}} \# \mathrm{y}_{\mathrm{t}-\mathrm{i}}+\mu_{1}
$$

For testing stationary our null hypothesis $(\mathrm{H} 0): \#=0$

$$
\text { Alternate hypothesis (H1): \# }<0
$$

\subsection{Engle-Granger Cointegration test}

If $Y_{t}$ and $X_{t}$ be two time series whose co-movement is to be tested. As a matter of first importance, both of these time series should be non-stationary. Furthermore, they ought to be integrated of the same order. To do this test, we continue as follows:

Firstly regress $Y_{t}$ on $X_{t}$ as: $Y_{t}=\#+\# X_{t}+\mu_{t}$

The evaluated residuals ought to be tested for stationary using Augmented Dickey Fuller test. In any case, while performing the test, the trend component ought not to be incorporated. Further, we should regress $X_{t}$ on $Y_{t}$ and acquire the residuals as mentioned above and test for its stationary utilizing ADF test. If the residuals of regression of $Y_{t}$ on 
$X_{t}$ and $X_{t}$ on $Y_{t}$ are both stationary, the two time series being referred to are co integrated.

\subsection{Granger causality test}

The dynamic linkage is analysed utilising the idea of Granger causality test. Assume $\mathrm{X}$ variable causes $\mathrm{Y}$; however $\mathrm{Y}$ does not granger cause $\mathrm{X}$, then past estimations of $X$ ought to have the capacity to anticipate future estimations of $Y$, but past estimations of $\mathrm{Y}$ should not be useful in the forecast of $\mathrm{X}$. The econometric process to assess if these two conditions hold comprises of two stages. To start with, we test the null hypothesis $\left(\mathrm{H}_{0}\right)$ that $\mathrm{X}$ does not cause $\mathrm{Y}$ by running the following regression equation:

Restricted equation:

$\mathrm{Y}=y=\sum_{i=1}^{\alpha} \alpha_{t}+y_{t-1}+\varepsilon_{t} \cdots \cdots$

And the unrestricted equation

$y=\sum_{i=1}^{\alpha} \alpha_{t} y_{t-1}+\sum_{t-1}^{\alpha} \beta_{1} x_{t-1}+\varepsilon_{t} \cdots \cdots$

F-test utilising the sum of squared residuals from every regression in order to test whether the group of coefficients B is significantly different from zero at some significance level is as follows.

$$
F=(N-K) \frac{\left(E s s r-E s s_{u r}\right)}{q\left(E s s_{u r}\right)}
$$

ESSr and ESSur are the sums of squared residuals in the restricted and unrestricted regressions; $\mathrm{N}$ is the number of observations; $\mathrm{k}$ is the number of estimated parameters in the unrestricted regression and $\mathrm{q}$ is the number of parameter restrictions. The statistic follows a $\mathrm{F}(\mathrm{q}, \mathrm{N}-\mathrm{k})$ distribution. We can reject the null hypothesis that "X does not cause $\mathrm{Y}^{\prime \prime}(\beta 1, \beta 2, \beta 3 \ldots \ldots \ldots \ldots x=0)$ if the group of coefficients added to the restricted regression is significantly different from zero. The next step is to test the null hypothesis " Y does not cause X". We should run the same regressions as above, but now switching $\mathrm{X}$ and $\mathrm{Y}$. If we cannot reject the null hypothesis that " $\mathrm{Y}$ does not cause $\mathrm{X}$ " then we can conclude that X Granger causes $Y$.

\subsection{Vector Autoregressive Analysis (VAR)}

Granger causality results have been checked through VAR results, in light of the fact that if one variable cause other variable, significant lead-lag relationship must exist 
between the two. For this reason we use a bi-variate VAR model of order p. VAR model the vectors of variables as autoregressive procedures where every variables of linearly depends on its lagged values and lagged values of other variables in the vector which suggests that future estimations of the procedure are a weighted sum of past and present values plus some noise and possible exogenous variables. Victor Autoregressive model (VAR) is given by Sims in 1980. A univariate auto regression is a single equation; single variable linear model in which the present estimation of a variable is clarified by its own lagged values. A VAR is an $n$-equation variable linear model in which every variable is in turn clarified by its own lagged values, in addition to, present and past values of remaining $\mathrm{n}-1$ variables. This basic system gives an efficient approach to catch dynamics in numerous time series. The VAR is normally utilised for forecasting frameworks of interrelated time series and for examining the dynamic effect of irregular disturbances on the system of interrelated time series and for analysing the dynamic impact of random disturbances on the system of variables.

\subsection{Empirical Analysis}

In order to understand the basic features of the selected variables firstly, we calculate the sample descriptive statistics (Table 1). We found that Jarque-Bera (JB) statistics is significant which clearly rejects the null hypothesis $\left(\mathrm{H}_{0}\right)$ that selected variables follow normal distribution.

Table 1: Descriptive Statistics

\begin{tabular}{|l|c|c|}
\hline \multicolumn{1}{|c|}{ Tests } & FIIs flows & Economic Growth \\
\hline Mean & 5341.79 & 0.02121 \\
\hline Median & 2501.12 & -0.004257 \\
\hline Maximum & 39268.45 & 0.255709 \\
\hline Minimum & -12137.69 & -0.108712 \\
\hline Std. dev. & 9514.623 & 0.097696 \\
\hline Skewness & 0.808951 & 0.675081 \\
\hline Kurtosis & 5.46651 & 3.99051 \\
\hline Jarque-Bera & $9.59673^{*}$ & $6.014129^{* *}$ \\
\hline Probability & 0.009351 & 0.050349 \\
\hline
\end{tabular}

*Significant at 1 percent level of significance

**Significant at 5 percent level of significance

\subsection{Unit root test results}

The unit root test checks whether a data series is stationary or not. Stationary condition has been examined utilising Augmented Dickey-Fuller (ADF). In order to 
check the forcefulness of relationship between Indian economic growth and FII investments and to think about the trend of data series between these two, Granger causality and VAR model have been applied, which require stationary of the variables in the framework. Since non-stationary variables does not come back to their long term average value following a disturbance, it is essential to change over such variables into a stationary process before including them into the VAR framework in order to stay away from spurious regression. On the premise of ADF, unit root test results, Table 2 demonstrates that FII flows and Indian economic growth are stationary at level.

Table 2: Unit Root Test Results

\begin{tabular}{|c|c|c|}
\hline Selected Variables & ADF Test (with constant) & ADF test (with constant and trend) \\
\hline FIIs flows & $-20.5134 *$ & $-20.4935^{*}$ \\
\hline Economic Growth & $-4.1525 * *$ & $-4.1150 * *$ \\
\hline
\end{tabular}

\subsection{Co-integration results}

The consequences of cointegration test keeping in mind the objective of the study to discover plausible presence of co-development between selected variables are exhibited in Table 3. The Table which displays the ADF stationary test of the residuals in the Engle Granger system, proposes that the residuals produced from all the pairwise co-integration investigation are observed to be non-stationary both at 1 percent and at 5 percent level. This induces that the selected variables that we have considered in the study don't show any co-movement between themselves. In this manner, it is clear from study that FII inflows are not essentially linked with the economic growth.

Table 3: Engle- Granger Co-integration Test Results

\begin{tabular}{|l|l|l|l|l|}
\hline Statement & $\begin{array}{l}\text { ADF Stats } \\
\text { (Computed values) }\end{array}$ & \multicolumn{2}{|l|}{$\begin{array}{l}\text { ADF Stats (Critical } \\
\text { values) }\end{array}$} & p- values \\
\hline $\begin{array}{l}\text { FII flows on Economic } \\
\text { Growth }\end{array}$ & -3.5121 & $\begin{array}{l}1 \text { percent } \\
-3.5721\end{array}$ & $\begin{array}{l}5 \text { percent } \\
-2.9565\end{array}$ & 0.0915 \\
\cline { 1 - 2 } $\begin{array}{l}\text { Economic Growth on } \\
\text { FIIs flows }\end{array}$ & -3.1019 & & 0.1705 \\
\hline
\end{tabular}




\subsection{Granger causality results}

In addition the co-integration activity to find out any potential presence of comovement between the selected variables; we additionally attempted the pair wise Granger causality test between FII inflows and GDP (proxy of economic growth). The results which are presented in Table 4 show that the null hypothesis $\left(\mathrm{H}_{0}\right.$ : No Granger causality) has been accepted. It clarifies that FII inflows are not significantly related with economic growth in India. Further, it has additionally been observed from the table that the hypothesis that economic growth does not bring about FII inflows in India is also accepted.

Table 4: Granger Causality Test Results

\begin{tabular}{|l|c|c|c|}
\hline \multicolumn{1}{|c|}{ Null Hypothesis $\left.\mathbf{H}_{\mathbf{0}}\right)$} & F-Stat & Probability & Inference \\
\hline $\begin{array}{l}\text { FII flows does not Granger } \\
\text { cause Economic Growth }\end{array}$ & 1.6509 & 0.3612 & Accepted \\
\hline $\begin{array}{l}\text { Economic Growth does not } \\
\text { Granger cause FIIs flows }\end{array}$ & 1.3701 & 0.4531 & Accepted \\
\hline
\end{tabular}

\subsection{VAR Model results}

We have verified the Granger causality results through VAR results. VAR results are presented in Table 5. The results show that economic growth does not influence FII inflows significantly. Further, it has additionally been clear from the table that FII inflows are not a substantial determinant of economic growth in India. Therefore, our results of VAR model further substantiate the results of Granger Causality test.

\subsection{Conclusions}

The present paper makes an effort to study cause and effect relationship between FIIs' inflows and economic growth in India. The study covers the period from 1994 to 2016. For the analysing the data we make use of quarterly information of Net FII inflows and GDP of India. The pragmatic relationship between FII inflows and economic growth has been examined by applying Engle-Granger Co-integration test, Granger Causality test and further VAR model. The results of the study have given no backing to the speculation that FII inflows have the capability of impacting the process of economic growth in India. Further, we have also found that economic growth is not a substantial determinant of FII inflows in India. Consequently, it clarifies that FII inflows in India are not pulled in by large scale economy advancement in India. In this manner, it can be sum 
92 | FOCUS: Journal of International Business, Volume 4, Issue 1, January-June 2017

up from the study that the real wealth of the country has not been increased with rise in FIIs inflows.

Table 5: Results of Lead- Lag relationship between FIIs flows and Economic growth

Panel A: Impact of FIIs flows on Economic Growth

\begin{tabular}{|l|l|l|l|l|l|}
\hline Variables & Coefficient & $\begin{array}{l}\text { Standard } \\
\text { Error }\end{array}$ & t-statistic & p-value & Sig. \\
\hline Constant & 0.02581 & 0.00721 & 3.0102 & 0.00460 & $*$ \\
\hline FII_1 & $5.52201 \mathrm{e}-07$ & $3.01110 \mathrm{e}-07$ & 1.8914 & 0.09134 & \\
\hline FII_2 & $1.13198-\mathrm{e} 07$ & $3.65405 \mathrm{e}-07$ & 0.3431 & 0.79653 & \\
\hline FII_3 & $-3.01345-\mathrm{e} 07$ & $3.89321 \mathrm{e}-07$ & -0.8654 & 0.54378 & \\
\hline FII_4 & $4.90135 \mathrm{e}-07$ & $4.01567 \mathrm{e}-07$ & 1.4456 & 0.21789 & \\
\hline Economic Growth_1 & -0.385461 & 0.1742104 & -3.3211 & 0.00693 & $*$ \\
\hline Economic Growth_2 & -0.40646 & 0.173111 & -3.3576 & 0.0040 & $*$ \\
\hline Economic Growth_3 & -0.34123 & 0.173571 & -3.1035 & 0.0110 & $* *$ \\
\hline Economic Growth_4 & 0.62816 & 0.11056 & 5.4510 & 0.0001 & $*$ \\
\hline
\end{tabular}

*significant at 1 percent level of significance

**significant at 5 percent level of significance

Panel B: Impact of Economic Growth on FIIs flows

\begin{tabular}{|l|l|l|l|l|l|}
\hline Variables & Coefficient & $\begin{array}{l}\text { Standard } \\
\text { Error }\end{array}$ & t-statistic & p-value & Sig. \\
\hline Constant & -1517.92 & 4112.15 & -0.3715 & 0.7315 & \\
\hline FII_1 & 0.6536 & 0.1815 & 3.9595 & 0.00042 & $*$ \\
\hline FII_2 & -0.08124 & 0.2175 & -0.4019 & 0.7172 & \\
\hline FII_3 & -0.1243 & 0.2179 & -0.5041 & 0.6149 & \\
\hline FII_4 & -0.00889 & 0.1932 & -0.0510 & 0.9815 & \\
\hline Economic Growth_1 & 72103.5 & 72051.1 & 1.9912 & 0.3453 & \\
\hline Economic Growth_2 & 39584 & 70031.5 & 0.5621 & 0.6123 & \\
\hline Economic Growth_3 & 79321.4 & 69247.2 & 1.1318 & 0.2935 & \\
\hline Economic Growth_4 & 51272.2 & -65139.5 & 0.7941 & 0.4913 & \\
\hline
\end{tabular}

*significant at 1 percent level of significance

**significant at 5 percent level of significance

The result of this study will be useful input into the regulatory process and can be kept into consideration while designing any effective changes in the policy. An insight of this issue is of great importance to policy makers who may be weighing the costs and benefits of the various economic liberalisation initiatives. In addition, the study 
results are of pertinent use of investment analyst, other institutional investors and domestic institutional investors. Further, the study results can also be used by research scholars of various disciplines like economics, international business, corporate finance and other social sciences as a basis for examining aspects such as return chasing behaviour, information asymmetry etc. Besides, the study results have strong implications for market efficiency and micro structure issues.

\section{References}

Aggarwal, R.N. (1997). Foreign portfolio investment in some developing countries: A study of determinants and macroeconomic impact. Indian Economic Review, 32(2), $217-$ 229.

Chakrabarti, Rajesh. (2001). FII flows to India: Nature and causes. Money and Finance, 2(7), 105-134.

Chitre, Vikas. (1996). Foreign capital flows and financial market in India. Journal of Foreign Exchange and International Finance, 4, 275-282.

Duttaray, Mousami, Dutt, A.K., \& Mukhopadhyay, Kajol. (2003). The relation between foreign direct investment and growth: Causality and mechanisms. Asian Development Review, 83,369-375.

Gangadhar, V. \& Reddy, G. N. (2008). The impact of foreign institutional investment on stock market liquidity and volatility in India. The Management Accountant, March, 5-20.

Gordon, J. \& Gupta, P. (2003). Portfolio flows into India: Do domestic fundamental matters? Working Paper No.03/20, International Monetary Fund.

Kumar, S. (2001). Does the Indian stock market play to the tune of FIIs investments? An empirical investigation. The ICFAI Journal of Applied Finance, 7(3), 36-44.

Lensik, R., Oliver, M. \& Osei, R. (1999). The impact of uncertain capital flows on economic growth in developing countries: An empirical analysis for the 1999's. Journal of International Finance, 12(2), 23-38. 
94 |FOCUS: Journal of International Business, Volume 4, Issue 1, January-June 2017

Ma, C. K. \& Kao, G. W. (1990). On exchange rate changes and stock price reactions. Journal of Business Finance and Accounting, 17, 441-449.

Merton, R. (1987). A simple model of capital market equilibrium with incomplete information. Journal of Finance, 42, 483-510.

Mishra, P.K., Das, K. B., \& Pradhan, B. B. (2010). Foreign institutional investments and real economic growth in India: A Causality Test. International Journal of Finance and Economics, 41, 212-219.

Misra, D., Mody, A. \& Murshid, A. P. (2001). Private capital flows and growth. A Quarterly Magazine of IMF, 38(2), 104-110.

Prasuna, C.A. (1999). Determinants of foreign institutional investment in India. Finance India, 14(2), 411-421.

Tripathy, N.P. (2007). Dynamic relationship between stock market, market capitalization and net FII investments in India. The ICFAI Journal of Applied Finance, 13(8), 60-68.

Trivedi, P. \& Nair, A. (2006). Determinants of FII investment in India. The ICFAI Journal of Applied Finance, 12(4), 5-20. 